\title{
Seasonal-to-interannual variability of chlorophyll-a bloom timing associated with physical forcing in the Gulf of Cádiz.
}

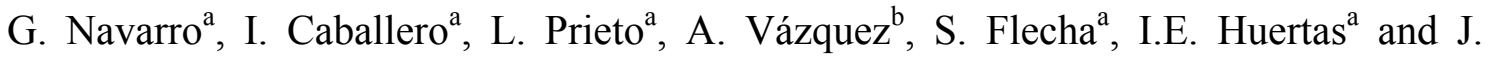
Ruiz ${ }^{\mathrm{a}}$.

${ }^{a}$ Instituto de Ciencias Marinas de Andalucía - ICMAN-CSIC, 11510, Puerto Real (Cádiz), Spain

${ }^{b}$ Departamento de Física Aplicada, Universidad de Cádiz, 11510, Puerto Real (Cádiz), Spain

Corresponding author: Gabriel.navarro@icman.csic.es

\section{Abstract}

Seasonal-to-interannual variability of the winter-spring bloom in the Gulf of Cádiz, eastern North Atlantic, has been investigated using chlorophyll- $a$ remote sensing (CHL). These data have been obtained from the GlobColour project; the temporal coverage extends from September 1997 to December 2010. In this study we develop a generic quantitative approach for describing the temporal variability in the shape of the winter-spring bloom within a region. Variability in both the timing and magnitude of the bloom in the basin has been evaluated as a function of physical properties in the water column such as mixed layer depth (MLD, GODAS model), sea surface temperature (SST, from AVHRR radiometers), photosynthetically-active radiation (PAR, from ocean color data) and euphotic depth $\left(Z_{\text {eu }}\right.$, from ocean color data). The analysis indicated that the timing, size and duration of the phytoplankton bloom in this area are largely controlled by both meteorological and oceanographic conditions at different scales; this means that it is likely to vary widely from one year to another.

Keywords: Gulf of Cádiz; timing of bloom; physical - biological forcing.

\section{Introduction}

Ocean phytoplankton is responsible for approximately half the net primary production of the global biosphere (Field et al, 1998). Satellite ocean-color observations have been used for some time to estimate global primary production (Longhurst, 1995; Behrenfeld and Falkowski, 1997). Recently, long-term change in global ocean surface chlorophyll- 
$a$ has been shown using satellite data (Martinez et al, 2009); contradictory results have been obtained regarding whether the global ocean biomass increased or decreased from the 1980s to the 2000s (Antonie et al, 2005; Greeg and Conkright, 2002). It has also been reported that the global phytoplankton concentration has declined over the past century (Boyce et al, 2010).

These changes in chlorophyll- $a$ concentration and primary production are attributed to variations in physical factors, such as wind, iron deposition and sea surface temperature (SST), associated with global climate changes (Behrenfeld et al, 2006). These studies have concluded that the global annual ocean primary production has decreased in recent years, corresponding with an increase in global SST of $0.2{ }^{\circ} \mathrm{C}$ over the same period (Gregg et al, 2003). Warmer ocean temperatures increase stratification of the surface mixed layer, which inhibits the entrainment of nutrients from lower depths to support ocean primary production (Sarmiento et al, 1998). In the North Atlantic Ocean, annual primary production has decreased by $7 \%$ over the last two decades, while SST has increased by $0.7^{\circ} \mathrm{C}$ and iron deposition decreased by $19 \%$ (Gregg et al, 2003).

The initial growth of the phytoplankton bloom has been associated also with variations in incident radiation and wind mixing (Townsend et al, 1994; Henson et al, 2006), in air-temperature (Nezlin et al, 2003), in sea surface temperature (Thomas et al, 2003), Asian dust (Jo et al, 2007) and in net heat flux (Azumaya et al, 2001); the timing of the bloom is important for the development of zooplankton (Rey et al, 1987), and has implications for higher trophic levels (Platt et al, 2003) and for the seasonality of the biological carbon pump (Eppley and Peterson, 1979). The classic quantitative description of bloom initiation was developed by Sverdrup (1953), who established that the vernal bloom is initiated when the surface mixed layer becomes shallower than the critical depth. Recently, several studies have been carried out in the North Atlantic ocean (Behrenfeld 2010, Boss and Behrenfeld, 2010), demonstrating that the Critical Depth hypothesis is an inadequate framework for understanding vernal blooms, and replacing it by the Dilution-Recoupling hypothesis (Behrenfeld, 2010); this most recent approach focuses on the balance between phytoplankton growth and grazing, and the seasonally-varying physical processes that influence this balance. 
One of the areas where the conditions required by Sverdrup`s 1953 hypothesis do not hold is the eastern north Atlantic south of $40^{\circ} \mathrm{N}$, where the Gulf of Cádiz is located (Fig. 1). Despite the geographic relevance of the Gulf for oceanographic research, only a few studies of ocean color time-series have been undertaken there with a view to understanding better the phytoplankton blooms using remote sensing data. Sousa and Bricaud (1992) initially described the pigment pattern in the area by analyzing daily images of the Coastal Zone Color Sensor (CZCS). Later, Peliz and Fiúza (1999) reported a complete study investigating the variability of surface pigments derived from the CZCS around the entire Portuguese coast but also briefly including the Gulf of Cádiz. Navarro and Ruiz (2006) analyzed the seasonal variability of chlorophyll- $a$ concentration in the continental shelf of the Gulf of Cádiz, and they investigated the differences between the spring bloom in the coastal areas and the winter-spring bloom in the open sea area.

The aim of this study is to analyze the seasonality and the generation of the bloom in the Gulf of Cádiz in the context of the Sverdrup (1953) versus Behrenfeld (2010) hypothesis. This understanding is then used to interpret the interannual variations of this seasonality in the basin associated with physical forcing. The analysis is performed in longer time and greater space resolution than previous studies of the northeastern Atlantic, thus providing more solid grounds on the conclusions obtained.

\section{Material and Methods}

\subsection{Ocean color images}

Ocean surface chlorophyll- $a$ data were downloaded from the GlobColour Project (http://www.globcolour.info/) which produces global ocean color maps (Level-3) by merging the data from the three sensors SeaWiFS, MODIS and MERIS, for the period between 1997 and the end of 2010. Surface chlorophyll- $a$ data corresponds to product Chlorophyll- $a$ Case I water based on GSM merging method (Maritorena and Siegel, 2005; Maritorena et al, 2010). This method provides the best fit to in-situ chlorophyll-a concentration and has the added advantages of providing other products and allowing to calculate pixel-by-pixel error bars. With these data sets the cloud cover is reduced and, therefore, more useful images become available. Spatial and temporal resolutions of these composite images were $4.6 \mathrm{~km}$ and 8 days respectively. The Region of Interest 
(ROI, $36^{\circ} 48^{\prime}-34^{\circ} 30^{\prime} \mathrm{N} ; 9^{\circ}-7^{\circ} \mathrm{W}$, Fig. 1) covers an area of $45,541 \mathrm{~km}^{2}$ and is located in the center of the Gulf of Cádiz, far from coastal areas that represent Case I water (Caballero et al, 2011). Time series were calculated by averaging arithmetically all valid pixels included in the ROI for each 8-days composite.

To model the annual bloom, 8-day chlorophyll- $a$ concentration composite values were fitted to a Gaussian function of time. This function has been used by other authors, first to analyze the vertical pigment profile (i.e. Platt et al, 1988; Bouman et al, 2000; Richardson et al, 2003), and subsequently, the time series of satellite-derived chlorophyll- $a$ values during the spring bloom, which also presents a similar distribution with an annual peak (Yamada and Ishizaka 2006; Platt et al, 2007; Platt et al, 2009). The Gaussian function for describing the time series of satellite-derived chlorophyll- $a$ (CHL) values is:

$\mathrm{CHL}(\mathrm{t})=\mathrm{CHL}_{\mathrm{o}}+\frac{\mathrm{h}}{\sigma \sqrt{2 \pi}} * \exp \left[-\frac{\left(\mathrm{t}-\mathrm{d}_{\max }\right)^{2}}{2 \sigma^{2}}\right]$,

where $\mathrm{CHL}_{\mathrm{o}}$ is the base-line chlorophyll- $a$ concentration $\left(\mathrm{mg} / \mathrm{m}^{3}\right), \mathrm{d}_{\max }$ (day) is the peak timing, $\sigma$ (day) is the standard deviation of the Gaussian curve and defines the width of the peak and the peak concentration is defined by $(\mathrm{h} / \sigma \sqrt{ } 2 \pi)$ where $\mathrm{h}\left(\mathrm{mg} / \mathrm{m}^{3}\right.$ day) is the integral of total satellite derived chlorophyll- $a$ values above the base-line. This model was fitted to the chlorophyll- $a$ data starting in September and ending in August of the following year, using the nonlinear least-squares method. For this model (Model 1), the initiation of the bloom was calculated as $d_{\max }-2 \sigma$. Moreover, two more model have been implemented to estimate the initiation of the bloom: the approach proposed by Platt et al (2009) that defines the initiation of the bloom as the time when the amplitude of the fitted curve reaches $20 \%$ of the amplitude of the Gaussian (Model 2) and the method by Siegel et al (2002), which provides a reasonable index for bloom initiation the day in which chlorophyll- $a$ rises 5\% above the annual median values (Model 3). This method has been also applied by Henson et al (2006) and Henson and Thomas (2007).

PAR images were obtained from the SeaWiFS sensor (September 1997 - December 2007) and from the MODIS sensor (January 2008 - December 2010) using individual 8day Level-3 SMI products, with $9 \mathrm{~km}$ of spatial resolution, obtained from NASA's Goddard Space Flight Center (http://oceancolor.gsfc.nasa.gov). Time series were 
calculated by averaging arithmetically all valid pixels included in the ROI for every 8days composite.

Net specific growth $\left(\mathrm{r}\right.$, on $\left.\mathrm{d}^{-1}\right)$ have been calculated from 8-day chlorophyll- $a$ satellite data for the ROI, following Behrenfeld (2010):

$$
\begin{array}{ll}
\mathrm{r}=\ln \left(\sum \mathrm{CHL}_{1} / \sum \mathrm{CHL}_{0}\right) / \Delta \mathrm{t} & \text { if MLD is deepening and }>\mathrm{Z}_{\mathrm{eu}} \\
\mathrm{r}=\ln \left(\mathrm{CHL}_{1} / \mathrm{CHL}_{0}\right) / \Delta \mathrm{t} & \text { if MLD is shoaling or }<\mathrm{Z}_{\mathrm{eu}}
\end{array}
$$

where $\mathrm{CHL}_{0}$ and $\sum \mathrm{CHL}_{0}$ are the initial chlorophyll- $a$ concentration, $\mathrm{CHL}_{1}$ and $\sum \mathrm{CHL}_{1}$ are the chlorophyll- $a$ concentration after the time interval $(\Delta \mathrm{t}=8$ days $)$ and $\sum \mathrm{CHL}=$ $\mathrm{CHL} * \mathrm{MLD}$, expressed as $\mathrm{mg} / \mathrm{m}^{2}$, which accounts for dilution of the population over a larger volume (Behrenfeld, 2010).

The euphotic depth $\left(Z_{\mathrm{eu}}\right.$, the depth at which the irradiance has decreased to $1 \%$ of the surface value) has been calculated according to the Lambert-Beer law and using the attenuation coefficient $\left(\mathrm{K}_{\mathrm{d}}\right)$ derived from K490 (Rochford et al, 2001) obtained from the GlobColour Project.

$\mathrm{K}_{\mathrm{d}}=0.0085+1.6243 * \mathrm{~K} 490($ where $\mathrm{K} 490<1)$,

$\mathrm{Z}_{\mathrm{eu}}=4.6052 / \mathrm{Kd}$,

A three-bin running boxcar averaging has been applied to ocean color products (CHL, $\mathrm{PAR}, \mathrm{r}$ and $\mathrm{Z}_{\mathrm{eu}}$ ) to dampen high frequency variability.

\subsection{Sea Surface Temperature (SST) data}

Pathfinder v5 SST data are derived from the five-channel Advanced Very High Resolution Radiometers (AVHRR) on board NOAA polar orbiting satellites. These SST data are a new reanalysis of the AVHRR data stream developed by the University of Miami's Rosenstiel School of Marine and Atmospheric Science (RSMAS) and the NOAA National Oceanographic Data Center (NODC).The product consists of a pair of 8day-composite global SST $\left({ }^{\circ} \mathrm{C}\right)$ fields at a spatial resolution of $4 \mathrm{~km}$, representing ascending (daytime) and descending (night-time) orbits separately. The data used from September 1997 to December 2009 of descending orbits. Pathfinder SST data are available via an anonymous ftp on the Jet Propulsion Laboratory (JPL) web site 
(ftp://podaac.jpl.nasa.gov). In the present analysis, the global SST data were subsampled to the region of interest including the quality data of the image. SST data were smoothed as described with the ocean color data.

\subsection{Mixed Layer Depth (MLD) data}

Mixed Layer Depth (MLD) data have been obtained from the operational data sets produced routinely by the Global Ocean Data Assimilation System (GODAS) developed at the National Centers for Environmental Prediction (NCEP). The binary data can be retrieved via ftp cfs.ncep.noaa.gov at directory pub/cfs/godas. The spatial resolution of the MLD data was $0.3^{\circ}$ in latitude and $1^{\circ}$ in longitude (Behringer and Xue, 2004), and the values were a 5-day composite (pentad). The data run from 1980 to 2010, and were smoothed similarly to ocean color and SST data. The date and the depth of the maxima MLD for each year were calculated from the times series.

\section{Results and discussion}

\subsection{Seasonal chlorophyll-a dynamics in the Gulf of Cádiz.}

Figure 1 displays the climatological chlorophyll- $a$ distribution in the basin that was calculated by averaging monthly values of chlorophyll- $a$ at each pixel for the whole study period (September 1997- December 2010). Following the general tendency of primary production in the ocean (i.e. Behrenfeld and Falkowski, 1997), this image shows the highest $\left(>10 \mathrm{mg} / \mathrm{m}^{3}\right)$ concentration and more standard deviation in coastal areas, mainly in the Iberian continental shelf whereas the lowest $\left(<0.1 \mathrm{mg} / \mathrm{m}^{3}\right)$ chlorophyll- $a$ appears in offshore waters, where the standard deviation is the lowest (Figure 1). These differences are due to the hydrological structures that govern the area. Navarro and Ruiz (2006) described the spatial and temporal patterns of chlorophyll- $a$ in several areas over the continental shelf and offshore, and Vargas et al (2003) defined the anticyclonic structure in the center of the basin that coincides with the oligotrophic area analyzed in this study.

The spatial and temporal pattern of chlorophyll- $a$ concentration in the ROI is illustrated in Fig. 2 and Fig. 3 respectively. Some common features that are clearly noticeable in the 13-year monthly climatology are the higher concentrations located on the north side with a pronounced north-south decrease. Figure 3 shows the climatological time series, 
calculated by averaging 8-days values of the 13 years, and the percentiles (5\% and 95\%) for chlorophyll- $a$ concentration from the GlobColour database in the ROI. The temporal evolution of the chlorophyll- $a$ values in the Gulf of Cádiz comprises two distinct regimes over the course of the year: the bloom period from winter to spring (maximum between February and April) and the non-bloom period from May to October, similar to that described in the Alborán Sea (García-Gorriz and Carr, 1999) and western Iberian Peninsula (Peliz and Fiúza, 1999). The mean chlorophyll- $a$ concentration fluctuated during the seasonal cycle between 0.1 and $0.35 \mathrm{mg} / \mathrm{m}^{3}$ over the year, with an overall average concentration of $0.15 \mathrm{mg} / \mathrm{m}^{3}$. These values reflect the oligotrophic nature of these waters. The greatest differences between percentiles were observed during the winter months, especially between February and April.

\subsection{Interannual variations of chlorophyll-a seasonality}

Chlorophyll- $a$ values from September 1997 to December 2010 clearly showed large variability (Fig. 4). High $\mathrm{CHL}_{\mathrm{SAT}}$ values were observed in late winter (February and March) each year, and low chlorophyll- $a$ concentration always occurred in summer. Chlorophyll- $a$ concentration varied from 0.08 to $0.6 \mathrm{mg} / \mathrm{m}^{3}$, which indicates an oligotrophic area similar to Pacific ocean (Wilson 2003) and Atlantic ocean (Peliz and Fiuza, 1999). The highest chlorophyll- $a$ concentration was observed in late winter in $2009\left(\approx 0.6 \mathrm{mg} / \mathrm{m}^{3}\right)$.

The use of a Gaussian function to fit the temporal variability of chlorophyll- $a$ allows to synthesize the dynamics of the blooming process in the Gulf of Cádiz and, therefore, facilitate its analyses in response to the physical forcing at different scales. Table 1 presents several parameters about the Gaussian fit, including peak amplitude $(\mathrm{h} / \sigma \sqrt{ } 2 \pi)$, peak timing $\left(\mathrm{d}_{\max }\right)$ and peak width $(\sigma)$ for each of the 13 years of analysis (Fig. 4). The quality of each curve fitting was assessed by calculating the determination coefficients $\left(\mathrm{R}^{2}\right.$; Table 1$)$. These coefficients were very high with a mean value of 0.93 (S.D. $\left.=0.03\right)$. In addition, several models have been used to calculate the initiation of the bloom (see section 2.1).

This parameterization permits to examine the interannual variations of chlorophyll- $a$ seasonality. The background chlorophyll- $a$ concentration $\left(\mathrm{CHL}_{\mathrm{o}}\right)$ generally had very low values $\left(<0.1 \mathrm{mg} / \mathrm{m}^{3}\right)$ whereas the peak amplitude ranged between 0.1 and 0.55 
$\mathrm{mg} / \mathrm{m}^{3}$ throughout the years (Table 1 ). The width of the bloom peak $(\sigma)$ varied between 19 and 54 days while the timing of the bloom peak $\left(\mathrm{d}_{\max }\right)$ ranged from the middle of January to the beginning of March, although it usually occurred in February. Mean and standard deviation of peak amplitude and $\sigma$ were $0.2408(\mathrm{SD}=0.1187) \mathrm{mg} / \mathrm{m}^{3}$ and 37 $(\mathrm{SD}=9.25)$ days, respectively.

The timing of the start of the bloom could be an indicator of inter-annual variability in phytoplankton bloom characteristics (Henson et al, 2006). Table 1 shows the dates of the initiation of the bloom calculated by different methods. The earliest bloom was observed in 1997/1998, starting at the end of September, and the latest bloom occurred in 2004/2005, starting on December 10 in 2004. Although individual divergences among models can be observed for some years (Fig. 4; Table 1), there were no overall statistical differences in the date of initiation of the bloom among the three models (ANOVA, $\mathrm{F}_{2,36}=1.51, \mathrm{P}<0.2$ ). Table 1 also evidences differences between Model 3 and the values assigned to this region in the work where this model is first described (Siegel et al, 2002). This discrepancy could emerge from differences in the spatial resolution of the analyses since Siegel et al. (2002) integrated the whole $35^{\circ}-40^{\circ} \mathrm{N}$ latitudinal band whereas we only integrated the eastern Atlantic between $36^{\circ} 48^{\prime}-34^{\circ} 30^{\prime} \mathrm{N}$. Besides the latitudinal differences involved, also there are longitudinal variations in the initiation of the bloom (Henson and Thomas, 2007).

\subsection{Physical forcing of the chlorophyll-a bloom.}

Figure 5 shows the temporal pattern of chlorophyll- $a, r$, MLD, euphotic depth $\left(Z_{\text {eu }}\right)$, SST and PAR for the same period than the chlorophyll- $a$ time series. There is a seasonal variation in MLD, with decreases in depth from more than $300 \mathrm{~m}$ in February-March to $25 \mathrm{~m}$ during the summer months. The evolution of MLD shows a large interannual variability (Fig. 5b) although there is a neat coincidence between the timing of MLD and chlorophyll- $a$ maxima $\left(\mathrm{d}_{\max }\right)$. A linear correlation analysis between the maximum depth of the MLD in winter and the peak amplitude of bloom suggests a cause-effect connection between these two parameters $(\mathrm{R}=0.83$ and $\mathrm{P}<0.001$, Table 2$)$, which is also observed between MLD and chlorophyll- $a$ integration $(h)(\mathrm{R}=0.54$ and $\mathrm{P}<0.05$, Table 2). In addition, the winter maximum depth is correlated with the duration of the bloom $(\mathrm{R}=-0.74$ and $\mathrm{P}<0.01$, Table 2$)$. During several years the initiation of the bloom (mean 
day of the three models) coincides with the time when the MLD extends below the euphotic layer ( $Z_{\text {eu }}$, Fig. 5).

There are some years, such as 2004, 2005, 2006 and 2009, when the determination coefficients have slight deviations (Table 1). For these years with two chlorophyll-a peaks, the Gaussian curve fit misses the first chlorophyll-a maximum, resulting in an apparent delay in the start of the bloom as reflected by the function parameters. This first peak is followed by events of atypically deep mixed layers $(>300 \mathrm{~m})$. Therefore, they can be interpreted as an interruption of the seasonal development of the bloom, owing to dilution and/or light limitations involved in severe entrainment events. The second peak after this interruption is singularly high in connection with an input of deep nutrient-rich waters to the surface (Koeve, 2001; Pätsch et al, 2002). Nutrient enrichment after entrainment can also generates the small rises in chlorophyll- $a$ observed in April 1998 and 2000.

The pattern of seasonal variations of SST and PAR in the ROI is illustrated in Fig. 5. Minimum SST in winter is correlated with winter maximum MLD ( $\mathrm{R}=-0.83$ and $\mathrm{P}<0.001$, Table 2) and peak intensity of bloom $(\mathrm{R}=-0.85$ and $\mathrm{P}<0.001$, Table 2$)$. In summer, the MLD minimum also coincides with the SST maximum, when there is maximum stratification in the area (Navarro et al, 2006). PAR intensity (Fig. 5c) does not correlate with peak bloom, duration or timing. These findings indicate that chlorophyll- $a$ patterns are not limited by light, and are in agreement with previous reports described in the Atlantic (Siegel et al, 2002) and in the Alborán Sea (GarcíaGorriz and Carr, 1999) at the same latitude. However, PAR is one of the key signals that govern the seasonal and latitudinal patterns of the phytoplankton biomass, along with the daily integrated light in the mixed layer that also locally modifies the effect of latitude on phytoplankton seasonality (Platt et al, 2009). In fact, there is a positive relationship between the initiation of the bloom (mean date of the three models) and the bloom peak ( $\mathrm{R}=0.71$ and $\mathrm{P}<0.01$, Table 2$)$, which indicates that if a blooms starts late, more PAR would be available during the bloom period, as the bloom initiation always occurs later than the PAR minimum in the time series.

The generic mechanism for the initiation of the bloom elucidated by Sverdrup (1953) is related to the rapid increase of insolation during the spring. However, this is not the case 
in the ROI latitude, as the PAR is at its minimum levels when the bloom is developing. In addition, Sverdrup (1953) emphasizes that the initiation of the bloom coincides in time with the mixed layer getting shallower in spring, whereas in the Gulf of Cádiz, the chlorophyll- $a$ increase occurs while the mixed layer is getting deeper.

Although the time of the maximum depth of MLD is visually correlated with the time of the chlorophyll- $a$ peak $\left(\mathrm{d}_{\max }\right)$, it has no effect in either bringing forward or delaying the late winter bloom (no correlation has been found between start and end timing of the bloom and the timing of the maximum depth of MLD). During each seasonal cycle, $r$ remains negative after the time of the bloom peak $\left(\mathrm{d}_{\max }\right)$ until early autumn, to subsequently increase in line with the rise of MLD and the decrease PAR (Fig 5). The maximum chlorophyll- $a$ concentration at $\mathrm{d}_{\max }$ represents the culmination of a positive population growth phase during the phytoplankton bloom, and this phase normally happens while the MLD is getting deeper. These data are consistent with the DilutionRecoupling hypothesis (Behrenfeld 2010): when the MLD is greater than the $Z_{\text {eu }}$, the balance between the phytoplankton specific growth rate and grazing is perturbed and the positive net growth phase is initiated for the annual winter bloom in the Gulf of Cádiz.

\section{Conclusions}

Results presented in this study neatly suggest the dominant role of the seasonal cycle in modulating the chlorophyll- $a$ evolution, as compiled by GlobColour time series for open-sea water in the Gulf of Cádiz. The interannual variability in chlorophyll- $a$ can be explained by changes in MLD among years. The coupling of MLD and chlorophyll- $a$ maxima in the ROI cannot be explained in the framework of the Critical Depth Hypothesis (Sverdrup, 1953). In disagreement with this hypothesis, the initiation of the bloom always occurs earlier than the maxima in the mixed layer during the entrainment period. The analysis of thirteen time series of open ocean oligotrophic waters in the Gulf of Cádiz is more coherent with the Dilution-Recoupling hypothesis recently formulated by Behrenfeld (2010).

\section{Acknowledgments}

We thank the ESA for distributing the GlobColour data used in this study, the JPL (NASA) for SST data and the NCEP for MLD data. This work was supported by 
research projects P09-RNM-4853, CTM2008-05680-C02-01/MAR, SESAME (FP6036949) and MedEX (CTM2008-04036-E/MAR).

\section{References}

Antoine, D., Morel, A., Gordon, H. R., Banzon, V. F., Evans, R. H. Bridging ocean color observations of the 1980s and 2000s in search of long-term trends. J. Geophys. Res. 110, C06009, 2005.

Azumaya, T., Isoda, Y., Noriki, S. Modeling of the spring bloom in Funka Bay, Japan. Cont. Shelf. Res. 21, 473-494, 2001.

Behrenfeld, M. J., Falkowski, P.G. Photosynthetic rates derived from satellite-based chlorophyll concentration. Limnol. and Ocean. 42 (1), 1-20, 1997.

Behrenfeld, M. J., O’Malley R. T., Siegel, D. A., McClain, C. R., Sarmiento, J. L, Feldman, G. C., Milligan, A. J., Falkowski, P. G., Letelier, R. M., Boss, E. S. Climatedriven trends in contemporary ocean productivity. Nature. 444, 752-755, 2006.

Behrenfeld, M. J. Abandoning Sverdrup's Critical Depth Hypothesis on phytoplankton blooms. Ecology. 91 (4), 997-1021, 2010.

Behringer, D. and Xue, Y. Evaluation of the global ocean data assimilation system at NCEP: The Pacific Ocean. Eighth Symposium on Integrated Observing and Assimilation Systems for Atmosphere, Oceans, and Land Surface, AMS 84th Annual Meeting, Washington State Convention and Trade Center, Seattle, Washington, 11-15, 2004.

Boss, E., Behrenfeld, M.J. In situ evaluation of the initiation of the North Atlantic phytoplankton bloom. Geophys. Res. Lett. 37, L18603, doi:10.1029/2010GL044174, 2010.

Bouman, H.A., Platt, T., Sathyendranath, S., Irwin, B.D., Wernand, M.R. Kraay, G.W. Bio-optical properties of the subtropical North Atlantic. II. Relevance to models of primary production. Mar. Ecol.-Prog. Ser. 200, 19-34, 2000.

Boyce, D. G., Lewis, M.R., Worm, B. Global phytoplankton decline over the past century. Nature. 466, 591-596, 2010.

Caballero, I., Ruiz, J. and Navarro, G. Dynamics of the turbidity plume in the Guadalquivir estuary (SW Spain): A remote sensing approach, IEEE Oceans 2011, Santander, Spain, 2011.

Eppley, R.W., Peterson, B.J. Particulate organic matter flux and planktonic new production in the deep ocean. Nature. 282, 677-680, 1979. 
Field, C. B., Behrenfeld, M. J., Randerson, J. T., Falkowski, P. Primary Production of the Biosphere: Integrating Terrestrial and Oceanic Components. Science. 281, 237-240, 1998.

García-Gorriz, E., Carr, M.E. The climatological annual cycle of satellite-derived phytoplankton pigments in the Alborán Sea. Geophys. Res. Lett. 26 (19), 2985-2988, 1999.

Gregg, W.W and Conkright, M.E. Decadal changes in global ocean chlorophyll, , 29, 15, doi:10.1029/2002GL014689, 2002.

Gregg, W. W., Conkright, M. E., Ginoux, P., O’Reilly, J. E., Casey, N. W. Ocean primary production and climate: Global decadal changes. Geophys. Res. Lett. 30, 1809, doi:10.1029/2003GL016889, 2003.

Henson, S. A., Robinson, I., Allen, J.T., Waniek, J.J. Effect of meteorological conditions on interannual variability in timing and magnitude of the spring bloom in the Irminger Basin, North Atlantic. Deep-Sea Res. II. 53 (10), 1601-1615, 2006.

Henson, S.A., Thomas, A.C. Interannual variability in timing of bloom initiation in the California Current System, J. Geophys. Res., 112, C08007, doi:10.1029/2006JC003960, 2007.

Jo, C.O., Lee, J.Y., Park, K.A., Kim, Y.H., Kim, K.R. Asian dust initiated early spring bloom in the northern East/Japan Sea. Geophys. Res. Lett., 34, L05602, doi:10.1029/2006GL027395, 2007.

Koeve, W. Wintertime nutrients in the North Atlantic-new approaches and implications for new production estimates. Mar. Chem. 74, 245-260, 2001.

Longhurst, A. R., Sathyendranath, S., Platt, T., Caverhill, C. An estimate of global primary production in the ocean from satellite radiometer data. J. Plankton Res. 17, 1245-1271, 1995.

Maritorena, S., Siegel, D. Consistent merging of satellite ocean color data sets using a bio-optical model. Remote Sens. Environ. 94, 429-440, 2005.

Maritorena, S., d'Andon, O.H.F., Mangin A., Siegel, D.A. Merged Satellite Ocean Color Data products using a bio-optical model: characteristics, benefits and issues, Remote Sens. Environ. 114, 1791-1804, 2010.

Martinez, E., Antoine, D., Fabrizio D’Ortenzio, Gentili, B. Climate-Driven Basin-Scale Decadal Oscillations of Oceanic Phytoplankton. Science. 326 (5957), 1253-1256, 2009.

Navarro, G., Ruiz, J., Huertas, I.E., García, C.M., Criado-Aldeanueva, F., Echevarría, F. Basin-scale structures governing the position of the deep fluorescence maximum in the Gulf of Cádiz. Deep-Sea Res. II. 53, 1261-1281, 2006. 
Navarro, G., Ruiz, J. Spatial and temporal variability of phytoplankton in the Gulf of Cádiz through remote sensing images. Deep-Sea Res. II. 53, 1241-1260, 2006.

Nezlin, N.P., Li, B.L. Time-series analysis of remote-sensed chlorophyll and environmental factors in the Santo Monica-San Pedro Basin off Southern California. J. Marine Sys. 39, 185-202, 2003.

Pätsch, J., Kuehn, W., Radach, G., Santana Casiano, J.M., Gonzalez Davila, M., Neuer, S., Freudenthal, T., Llinas, O. Interannual variability of carbon fluxes at the North Atlantic Station ESTOC. Deep-Sea Res. II. 49, 253-288, 2002.

Peliz, A.J., Fiúza, A.F.G. Temporal and spatial variability of CZCS-derived phytoplankton pigment concentrations off the western Iberian Peninsula. Int. J. Remote Sensing. 20 (7), 1363-1403, 1999.

Platt, T., Sathyendranath, S., Caverhill, C.M., Lewis, M. R. Ocean primary production and available light: further algorithms for remote sensing. Deep-Sea Res. I. 35 (6), 855879, 1988.

Platt, T., Fuentes-Yaco, C., Frank, K.T. Spring algal bloom and larval fish survival. Nature. 423, 398-399, 2003.

Platt, T., Sathyendranath, S., Fuentes-Yaco, C. Biological oceanography and fisheries management: perspective after 10 years. ICES J. Mar. Sci. 64(5), 863-869, 2007.

Platt, T, White, G. N., Zhai, L., Sathyendranath, S., Roy, S. The phenology of phytoplankton blooms: Ecosystem indicators from remote sensing. Ecol. Model. 2220, 3057-3069, 2009.

Rey, F., Skjoldal, H.R., Slagstad, D. Primary production in relation to climate changes in the Barents Sea, in: Loeng Bergen, H. (Ed.), The Effect of Oceanographic Conditions on Distribution and Population Dynamics of Commercial Fish Stocks in the Barents Sea. Institute of Marine Research, pp. 29-46, 1987.

Richardson A.J., Silulwane, N.F., Mitchell-Innes, B.A., Shillington, F.A. A dynamic quantitative approach for predicting the shape of phytoplankton profiles in the ocean. Prog. Oceanogr. 59, 301-319, 2003.

Rochford, P.A., Kara, A.B., Wallcraft, A.J., Arnone, R.A. Importance of solar subsurface heating in ocean general circulation models. J. Geophys. Res. 106 (C11), 30923-30938, 2001.

Sarmiento, J. L., Hughes, T. M. C., Stouffer, R. J., Manabe, S. Simulated response of the ocean carbon cycle to anthropogenic climate warming. Nature. 393, 245-249, 1998.

Siegel, D.A., Doney, S.C., Yoder, J.A. The North Atlantic Spring Phytoplankton Bloom and Sverdrup's Critical Depth Hypothesis. Science 296, 730-733, 2002. 
Sousa, F., Bricaud, A. Satellite-derived phytoplankton pigments structures in the Portuguese upwelling area. J. Geophys. Res. 97 (C7), 11343-11356, 1992.

Sverdrup, H.U. On conditions for the vernal blooming of phytoplankton. Journal du Conseil Permanent International Pour L'Exploration de la Mer. 18, 287-295, 1953.

Thomas, A.C., Townsend, D.W., Weatherbee, R. Satellite measured phytoplankton variability in the Gulf of Maine. Cont. Shelf. Res. 23, 971-989, 2003.

Townsend, D.W., Cammen, L.M., Holligan, P.M., Campbell, D.E., Pettigrew, N.R. Causes and consequences of variability in the timing of spring phytoplankton blooms. Deep-Sea Res. I. 41 (5-6), 747-765, 1994.

Vargas, J.M., Garcia-Lafuente, J., Delgado, J., Criado, F. Seasonal and wind-induced variability of sea surface temperature patterns in the Gulf of Cádiz. J. Marine Sys. 38 (3-4), 205-219, 2003.

Wilson, C. Late Summer chlorophyll blooms in the oligotrophic North Pacific Subtropical Gyre. Geophys. Res. Lett 30, 1942, doi:10.1029/2003GL017770, 2003.

Yamada, K., Ishizaka, J. Estimation of interdecadal change of spring bloom timing, in the case of the Japan Sea. Geophys. Res. Lett. 33, L02608, doi:10.1029/2005GL024792, 2006. 


\section{Figure captions}

Figure 1. Images of average chlorophyll- $a$ values (left, in $\mathrm{mg} / \mathrm{m}^{3}$ ) and standard deviation (right, in $\mathrm{mg} / \mathrm{m}^{3}$ ) for the Gulf of Cádiz between September 1997 and December 2010. The yellow box area represents the ROI for this study. The contour lines represent the bathymetry (in meters).

Figure 2. The 13-year (September 1997 - December 2010) monthly mean Chlorophyll$a\left(\right.$ in $\left.\mathrm{mg} / \mathrm{m}^{3}\right)$ distribution for the ROI located at the Gulf of Cádiz.

Figure 3. Annual mean cycle from January to December of chlorophyll- $a$ values (open symbol) and 5 and 95 percentiles (solid lines) between September 1997 and December 2010 .

Figure 4. Thirteen-year record of 8-day chlorophyll- $a$ values (green line) and Gaussian function (blue line) fitted to the chlorophyll- $a$ data every year bloom (from September to August of the next year). Vertical dashed lines represents the date (YD init) of the initiation of the bloom following several models. Model 1: Yamada and Ishizaka (2006); Model 2: Platt et al (2009) and Model 3: Siegel et al (2002).

Figure 5. a) Time series of chloropyhll-a values (green line, left axis) and phytoplankton net specific growth rate (black line, right axis). b) Time series of MLD (blue line, left axis) and euphotic depth (black line, right axis). c) Time series of SST (blue line, left axis) and PAR (black line, right axis). Vertical solid and dashed red lines indicate the timing of the bloom peak $\left(\mathrm{d}_{\max }\right)$ and the start of the bloom (averaged day between the three models) respectively.

\section{Table Captions.}

Table I. Parameters obtained from the Gaussian fit for the bloom each year. $C H L_{o}$ is the base-line chlorophyll- $a$ concentration, Peak amplitude $(h / \sigma \sqrt{ } 2 \pi), \sigma$ defines the width of the peak, the date of the initiation of the bloom (dates and Julian day) calculated by three models (Model 1: Yamada and Ishizaka, [2006]; Model 2: Platt et al., [2009]; and Model 3: Siegel et al, [2002]). $d_{\max }$ is the date of the peak timing (date and Julian day) and $\mathrm{R}^{2}$ is the coefficient of determination of the Gaussian fit.

Table II. Correlation coefficients of a) maximum MLD to various parameters of Gaussian fit and physical factors $\left(\mathrm{SST}_{\min }\right), \mathrm{b}$ ) chlorophyll- $a$ peak to the start of the bloom (mean date of the three models) and physical factors ( $\left.\mathrm{SST}_{\text {min }}\right)$. 


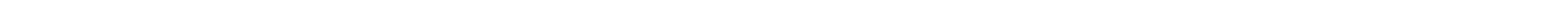




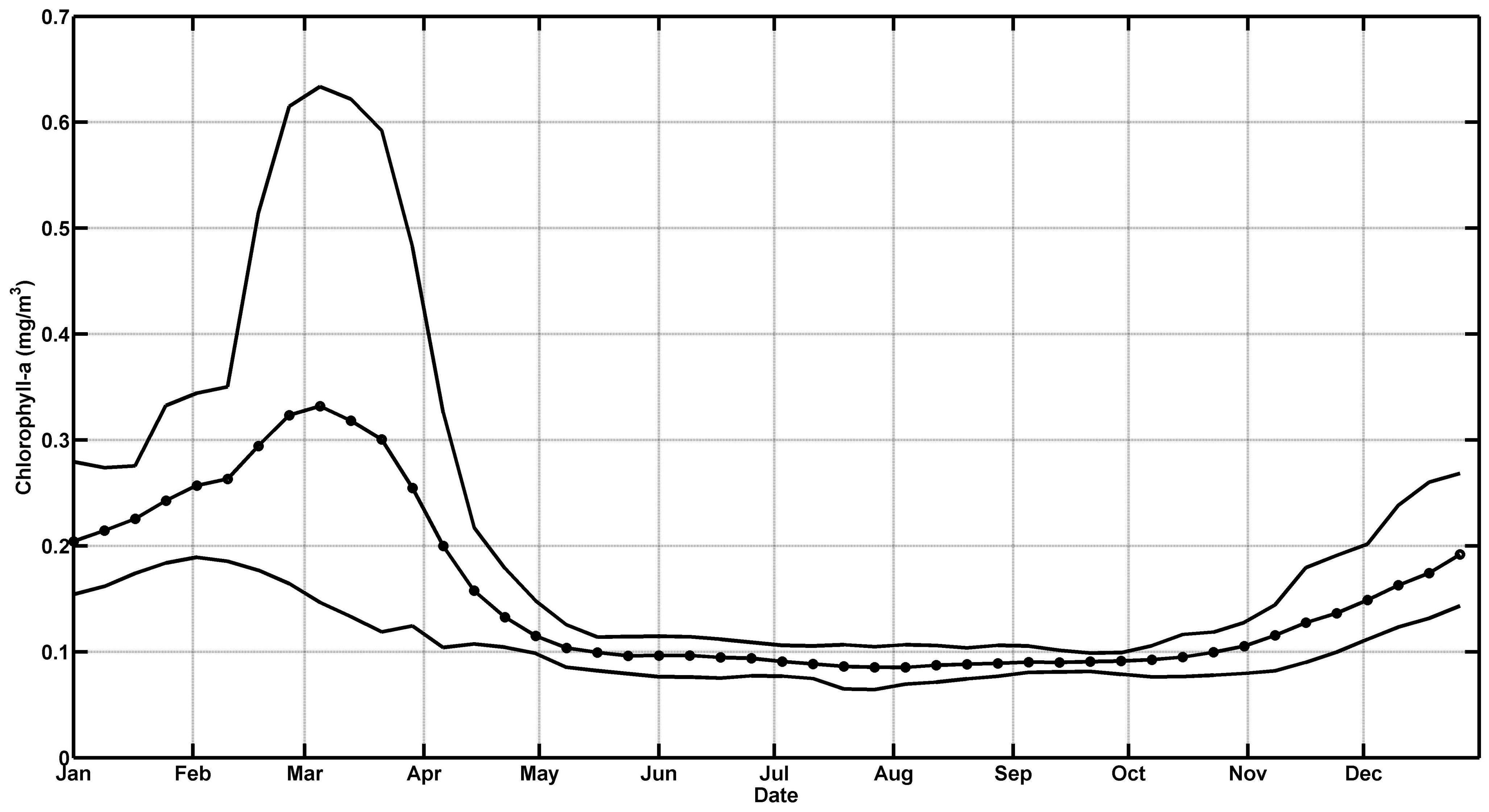



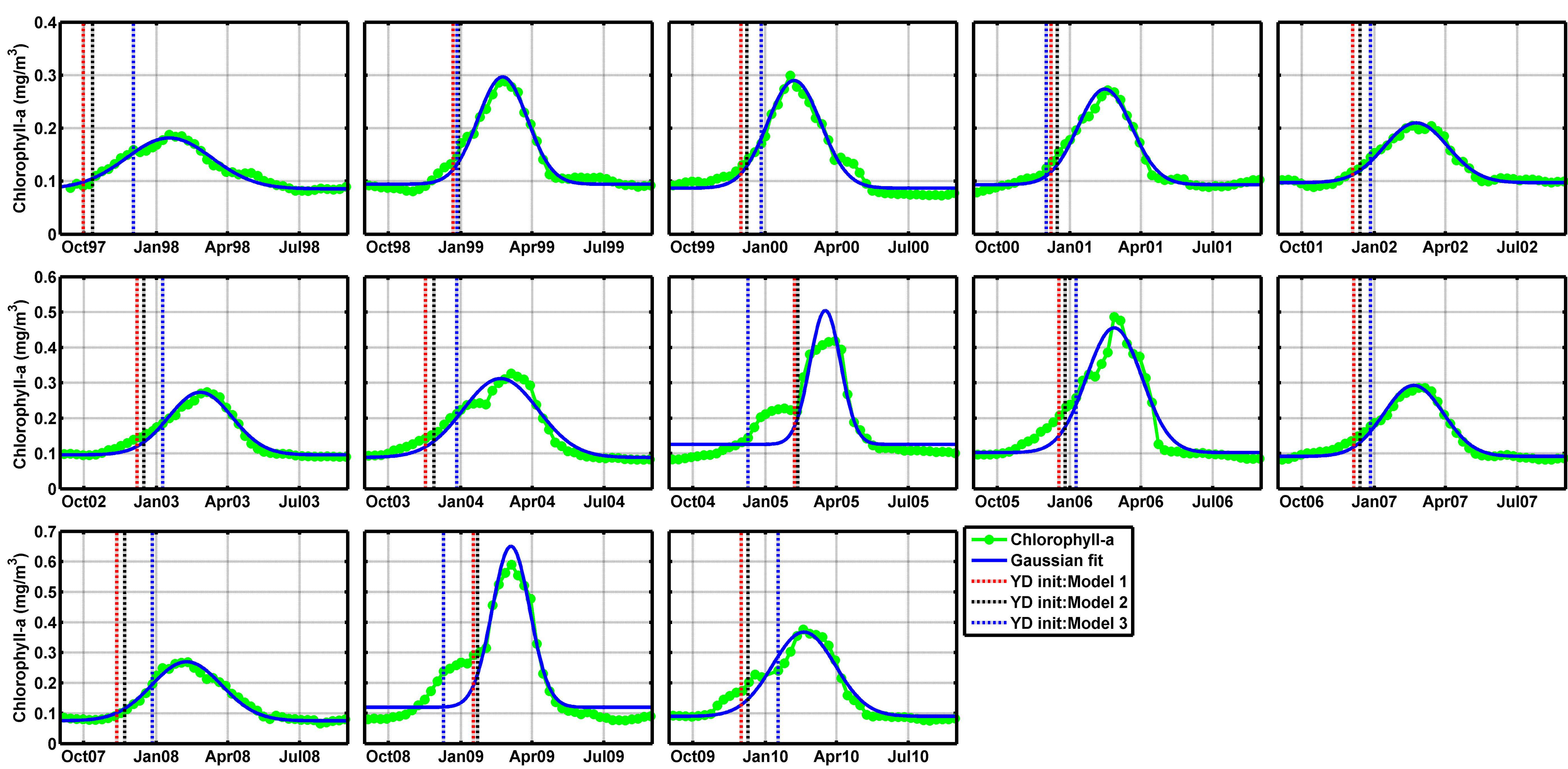

\section{$\rightarrow-$ Chlorophyll-a}

\section{- Gaussian fit}

........ YD init:Model 1

....... YD init:Model 2

..... YD init:Model 3 
Table I. Parameters obtained from the Gaussian fit for the bloom each year. $C H L_{o}$ is the base-line chlorophyll concentration, Peak amplitude $(h / \sigma \sqrt{ } 2 \pi), \sigma$ defines the width of the peak, the date of the initiation of the bloom (dates and Julian day) calculated by three models (Model 1: Yamada and Ishizaka, [2006]; Model 2: Platt et al., [2009]; and Model 3: Siegel et al, [2002]). $d_{\max }$ is the date of the peak timing (date and Julian day) and $\mathrm{R}^{2}$ is the coefficient of determination of the Gaussian fit.

\begin{tabular}{|c|c|c|c|c|c|c|c|c|}
\hline \multirow{2}{*}{$\begin{array}{l}\text { Year of } \\
\text { bloom }\end{array}$} & \multirow{2}{*}{$\begin{array}{l}\mathrm{CHL}_{\mathbf{0}} \\
\mathrm{mg} / \mathrm{m}^{3}\end{array}$} & \multirow{2}{*}{$\begin{array}{c}\text { Peak } \\
\mathrm{mg} / \mathrm{m}^{3}\end{array}$} & \multirow{2}{*}{$\underset{\text { days }}{\sigma}$} & \multicolumn{3}{|c|}{ Start of bloom (date/Julian day) } & \multirow{2}{*}{$\begin{array}{c}d_{\max } \\
\text { (date) }\end{array}$} & \multirow[t]{2}{*}{$\mathbf{R}^{2}$} \\
\hline & & & & Model 1 & Model 2 & Model 3 & & \\
\hline $\begin{array}{l}1997 / \\
1998\end{array}$ & 0.0856 & 0.0960 & 54.34 & $\begin{array}{c}09 / 30 / 1997 \\
273\end{array}$ & $\begin{array}{c}10 / 12 / 1997 \\
285\end{array}$ & $\begin{array}{c}12 / 03 / 1997 \\
337\end{array}$ & $\begin{array}{c}01 / 17 / 1998 \\
17\end{array}$ & 0.94 \\
\hline $\begin{array}{l}1998 / \\
1999\end{array}$ & $\overline{94}$ & 2024 & 30 & $\begin{array}{c}12 / 21 / 1998 \\
355\end{array}$ & $\begin{array}{c}12 / 29 / 1998 \\
363\end{array}$ & $\begin{array}{c}12 / 27 / 1998 \\
361\end{array}$ & $\begin{array}{c}02 / 22 / 1999 \\
53\end{array}$ & 0.96 \\
\hline $\begin{array}{l}1999 / \\
2000\end{array}$ & 0869 & 2030 & 33.73 & $\begin{array}{c}12 / 01 / 1999 \\
335\end{array}$ & $\begin{array}{c}12 / 09 / 1999 \\
343\end{array}$ & $\begin{array}{c}12 / 27 / 1999 \\
361\end{array}$ & $\begin{array}{c}02 / 06 / 2000 \\
37\end{array}$ & 0.94 \\
\hline $\begin{array}{l}2000 / \\
2001\end{array}$ & 0.0934 & 0.1804 & 33.96 & $\begin{array}{c}12 / 08 / 2000 \\
343\end{array}$ & $\begin{array}{r}12 / 16 \\
35\end{array}$ & $\begin{array}{c}12 / 02 / 2000 \\
337\end{array}$ & $\begin{array}{c}02 / 14 / 2001 \\
45\end{array}$ & 0.93 \\
\hline $\begin{array}{l}2001 / \\
2002\end{array}$ & 0.0972 & 0.1128 & 40.03 & $\begin{array}{c}12 / 04 / 2001 \\
338\end{array}$ & $\begin{array}{r}12 / 14 \\
34\end{array}$ & $\begin{array}{c}12 / 27 / 2001 \\
361\end{array}$ & $\begin{array}{c}02 / 22 / 2002 \\
53\end{array}$ & 0.97 \\
\hline $\begin{array}{l}2002 / \\
2003\end{array}$ & 0.0961 & 0.1769 & 40.06 & $\begin{array}{c}12 / 07 / 2002 \\
341\end{array}$ & $\begin{array}{c}12 / 16 / 2002 \\
350\end{array}$ & $\begin{array}{c}01 / 09 / 2003 \\
9\end{array}$ & $\begin{array}{c}02 / 25 / 2003 \\
56\end{array}$ & 0.95 \\
\hline $\begin{array}{l}2003 / \\
2004\end{array}$ & 0 & 0.2231 & 47.54 & $\begin{array}{r}11 / 17 \\
32\end{array}$ & $\begin{array}{c}11 / 28 / 2003 \\
332\end{array}$ & $\begin{array}{c}12 / 27 / 2003 \\
361\end{array}$ & $\begin{array}{c}02 / 20 / 2004 \\
51\end{array}$ & 0.89 \\
\hline $\begin{array}{l}2004 / \\
2005\end{array}$ & 0.1257 & $0.5 / 00$ & 19.45 & $\begin{array}{c}02 / 06 / 2005 \\
37\end{array}$ & $\begin{array}{c}02 / 11 / 2005 \\
42\end{array}$ & $\begin{array}{c}12 / 10 / 2004 \\
345\end{array}$ & $\begin{array}{c}03 / 17 / 2005 \\
76\end{array}$ & 0.87 \\
\hline $\begin{array}{l}2005 / \\
2006\end{array}$ & 0.1024 & 0.3530 & 34.90 & $\begin{array}{c}12 / 18 / 2005 \\
352\end{array}$ & $\begin{array}{c}12 / 26 / 2005 \\
360\end{array}$ & $\begin{array}{c}01 / 09 / 2006 \\
9\end{array}$ & $\begin{array}{c}02 / 25 / 2006 \\
56\end{array}$ & 0.90 \\
\hline $\begin{array}{l}2006 / \\
2007\end{array}$ & 0.0916 & 0.2008 & 37.74 & $\begin{array}{c}12 / 06 / 2006 \\
340\end{array}$ & $\begin{array}{c}12 / 14 / 2006 \\
348\end{array}$ & $\begin{array}{c}12 / 27 / 2006 \\
361\end{array}$ & $\begin{array}{c}02 / 19 / 2007 \\
50\end{array}$ & 0.96 \\
\hline $\begin{array}{l}2007 / \\
2008\end{array}$ & 0.0754 & 0.1945 & 44.19 & $\begin{array}{c}11 / 12 / 2007 \\
316\end{array}$ & $\begin{array}{c}11 / 22 / 2007 \\
326\end{array}$ & $\begin{array}{c}12 / 27 / 2007 \\
361\end{array}$ & $\begin{array}{c}02 / 08 / 2008 \\
39\end{array}$ & 0.97 \\
\hline $\begin{array}{l}2008 / \\
2009\end{array}$ & 0.1199 & 0.5308 & 23.79 & $\begin{array}{c}01 / 16 / 2009 \\
16\end{array}$ & $\begin{array}{c}01 / 22 / 2009 \\
22\end{array}$ & $\begin{array}{c}12 / 10 / 2008 \\
345\end{array}$ & $\begin{array}{c}03 / 05 / 2009 \\
64\end{array}$ & 0.89 \\
\hline $\begin{array}{l}2009 / \\
2010\end{array}$ & 0.0901 & 0.2777 & 39.68 & $\begin{array}{c}12 / 01 / 2009 \\
335\end{array}$ & $\begin{array}{c}12 / 10 / 2009 \\
344\end{array}$ & $\begin{array}{c}01 / 17 / 2010 \\
17\end{array}$ & $\begin{array}{c}02 / 18 / 2010 \\
49\end{array}$ & 0.91 \\
\hline
\end{tabular}


Table II. Correlation coefficients of a) maximum MLD to various parameters of Gaussian fit and physical factors $\left.\left(\mathrm{SST}_{\min }\right), \mathrm{b}\right)$ chlorophyll-a peak to the start of the bloom (mean date of the three models) and physical factors ( $\left.\mathrm{SST}_{\mathrm{min}}\right)$.

\begin{tabular}{|c|c|c|c|c|}
\hline a) & Peak & h & $\boldsymbol{\sigma}$ & SSTmin \\
\hline MLDmax & 0.83 & 0.54 & -0.74 & -0.83 \\
& $\mathrm{P}<0.001$ & $\mathrm{P}<0.05$ & $\mathrm{P}<0.01$ & $\mathrm{P}<0.001$ \\
\hline
\end{tabular}

\begin{tabular}{|l|c|c|}
\hline b) & Start of bloom & SSTmin \\
\hline CHL-a Peak & 0.71 & -0.85 \\
& $\mathrm{P}<0.01$ & $\mathrm{P}<0.001$ \\
\hline
\end{tabular}

